A. Weisbecker, M. Burmester \& A. Schmidt (Hrsg.): Mensch und Computer 2015 Workshopband, Stuttgart: Oldenbourg Wissenschaftsverlag, 2015, S. 155-163.

\title{
Smart Factories: Mitarbeiter-zentrierte Informationssysteme für die Zusammenarbeit der Zukunft
}

\author{
Alexander Stocker ${ }^{1}$, Andrea Denger ${ }^{1}$, Martin Wifling ${ }^{1}$, Johannes Fritz ${ }^{1}$, \\ Christian Kaiser ${ }^{1}$, Christian Kittl ${ }^{2}$, Alexander Richter ${ }^{3}$ \\ Information \& Process Management, Virtual Vehicle Research Center ${ }^{1}$ \\ evolaris next level $\mathrm{GmbH}^{2}$ \\ Department of Informatics, University of Zurich ${ }^{3}$
}

\section{Zusammenfassung}

In Unternehmen mit komplexen Produkten und Dienstleistungen wachsen Anforderungen, welche an Kommunikation, Koordination und Zusammenarbeit zwischen Informations- und Wissensarbeitern gestellt werden, stetig. Dieser Workshop will vor dem Hintergrund des durch die Initiatoren im Factory of the Future Programm gestarteten EU-Projects FACTS4WORKERS eine nachhaltige Plattform schaffen, um aktuelle und zukünftige Fragestellungen rund um den Einsatz neuer, nutzerzentrierter Informationssysteme und -technologien in Industrieunternehmen interdisziplinär zu diskutieren. Der Workshop baut auf eine ganze Reihe vorangegangener Workshops auf, welche das Thema soziale Interaktion in Organisationen aus unterschiedlichen Gesichtspunkten beleuchtet haben. Er spricht daher auch Praktiker und Wissenschaftler an, die in den letzten Jahren an diesen Workshops teilgenommen haben und möchte diese Community und die betrachteten Fragestellungen erweitern.

\section{$1 \quad$ Einleitung}

Ausgehend vom namensgleichen Workshop im Rahmen der Mensch und Computer 2014 knüpft die diesjährige Ausgabe nahtlos an den damals aufgebrachten Themen an: Smart Factory, Industrie 4.0, Mensch-Maschinen-Kollaboration und weitere. Die Entwicklung komplexer Produkte und Services (cyber-physikalische Systeme bzw. Smart Connected Products (Porter und Heppelmann, 2014)) bedarf einer idealen Systemumgebung. Das bedingt ein optimales Zusammenspiel zwischen Mensch, Prozess, Kultur und Technologie. Für den Menschen ergeben sich aus der fortschreitenden Entwicklung zu Prosumer bzw. Intrapreneuren völlig neue Anforderungen an betriebliche Informationssysteme, wie aktuelle 
Arbeiten zeigen, z.B. Spath et al. (2014), Richter (2014), Stocker und Tochtermann (2012), Denger et al. (2012), oder Denger et al. (2014)).

Auch die Wirtschaftsinformatik (WI) hat diese Entwicklungen in der Zwischenzeit berücksichtigt: Gemäß einer aktuelleren WI-Definition von Hansen und Neumann (2009) besteht ein Informationssystem aus Menschen und Maschinen, die Informationen erzeugen und/oder benutzen und die durch Kommunikationsbeziehungen miteinander verbunden sind. Aus einem Informationssystem ist der Faktor Mensch somit nicht mehr wegzudenken. Neben der Erstellung von Inhalten spielt gerade eine optimale Kommunikation zwischen Menschen eine wesentliche Rolle in der betrieblichen Leistungserstellung. Es lässt sich auch von Ebenen der sozialen Interaktion sprechen, wenn beispielsweise wie im 3K Modell (Teufel 1995), Kommunikation, Koordination und Kooperation unterschieden werden. Moderne Informationssysteme sollen auch in der Lage sein, die unterschiedliche Ebenen der sozialen Interaktion in Smart Factories zu unterstützen. Aus Sicht von CSCW steht das soziotechnische Systemverständnis seit jeher im Vordergrund.

In der Projektpraxis am Virtual Vehicle Research Center hat sich gezeigt, dass gerade in technologieorientierten Unternehmen der Automobilindustrie vor dem Hintergrund großer Produkt- und Variantenvielfalt immense Herausforderungen an die Kommunikation und Zusammenarbeit zwischen Wissensarbeitern gestellt werden. Lösungen werden zwar oft in der Automatisierung gesucht, doch auch in Bewegungen wie der von Deutschland ausgehenden Industrie 4.0 (Spath et al. 2013) wird der Mensch künftig eine wesentliche Rolle spielen. Mit Industrie 4.0 werden die unterschiedlichsten Trends rund um die Weiterentwicklung von Produktionsstätten zusammengefasst. Mit dem Einzug des Internet in die Produktion und seiner zahlreichen Facetten (Internet of Data, Services, and Things) soll ein viertes industrielles Zeitalter anbrechen, das durch die zunehmende Informatisierung nicht nur einzelner Fabriken sondern ganzer Produktionswertschöpfungsnetzwerke zur Schaffung von Mehrwert und Arbeitsplätzen führt. Ein Großteil dieser Entwicklungen wird durch die Player der IKT-Industrie forciert, und Industrie 4.0 benennt damit oft nur die fortlaufende Informatisierung klassischer Fabriken (Stocker et al, 2014). Doch viele Experten, die Organisatoren dieses Workshops inkludiert, sind der Ansicht, dass gerade der Mensch in Zukunft als Wissensarbeiter der Produktion eine wesentliche Drehscheibe darstellen wird.

Mitarbeiterzentrierung in Smart Factories ist auch das zentrale Thema des, im Horizon 2020 Programm Factory of the Future durch die Initiatoren gemeinsam mit renommierten Produktionsbetrieben und anderen wissenschaftlichen Partnern eingereichten, EU-Projektes FACTS4WORKERS: Worker-Centric Workplaces in Smart Factories, welches nach der Förderzusage durch die Europäische Kommission Ende 2014 erfolgreich gestartet worden ist. In FACTS4WORKERS werden entlang der vier Anwendungsfälle Assistierter Bediener, Produktions-Wissensmanagement, Selbstlernender Arbeitsplatz und Mobiles Lernen in der Produktion innovative und nutzernahe Informationssysteme entwickelt. Dabei steht nicht nur die bloße Steigerung von Qualität und Produktivität im Vordergrund. Vielmehr geht es darum, soziale Aspekte wie Zufriedenheit, Motivation und Innovationsfähigkeit von Mitarbeitenden in der Produktion und damit die Attraktivität der Produktionsarbeit insgesamt zu erhöhen. Es gilt damit systematisch zu hinterfragen, wie Menschen heute arbeiten und lernen, wie sie mit 
neuen Informationstechnologien interagieren und wie sie an einem attraktiven und fordernden Produktionsarbeitsplatz einen Mehrwert für die Industrie erzeugen können.

\section{Zentrale Fragestellungen des Workshops}

In Bezug auf die Unterstützung von Kommunikation und Zusammenarbeit in Smart Factories durch neuartige Informationssysteme lassen sich wesentliche Fragestellungen definieren und nach den Teilsystemen, Mensch, Organisation und Technologie strukturieren:

Aus Sicht von Menschen, z.B.

Wie unterscheiden sich Ansprüche von Ingenieuren oder Produktionsmitarbeitenden an Informationssysteme zur Unterstützung sozialer Interaktion?

Wie können Ingenieure oder Produktionsmitarbeitenden motiviert werden, neuartige Informationssysteme in Smart Factories einzusetzen?

Welche Anwendungsfälle können neue mitarbeiterzentrierte Informationssysteme in Smart Factories überhaupt unterstützen?

Aus Sicht der Organisation, z.B.

Wie können neue mitarbeiterzentrierte Informationssysteme in bestehende Prozesse und Kulturen - und insbesondere in Produktionsumgebungen - eingebettet werden?

Welche organisationalen Rahmenbedingungen befürworten/verhindern derzeit die Aneignung mitarbeiterzentrierter Informationssysteme in Smart Factories?

Wie können optimale Organisations- und Informationsstrukturen für Smart Factories ausgestaltet sein?

Aus Sicht der Technologie, z.B.

Welche technologischen Ansätze wurden bisher entwickelt, um Kommunikation und Zusammenarbeit in Smart Factories zu unterstützen?

Wie wirken sich in diesem Zusammenhang insbesondere neuartige Technologien, die unter dem Begriff Wearable Devices zusammengefasst werden, aus?

Wie setzen Industriebetriebe Wissensmanagement-Systeme, Social Software, Enterprise Search und Co-Creation insb. in der Produktion ein - und was sind Lessons Learned?

Themen des Workshops: Speziell von Interesse sind Beiträge zu den folgenden Themen:

Methoden, Modelle und Technologien für Wissens- und Informationsmanagement mit Social Software in Smart Factories

Prozeduren und Praktiken für effektives Wissensmanagement mit Social Software in Smart Factories 
Evaluation des Einsatzes von Social Software in Smart Factories (z.B. mit Hilfe von Mixed-Method-Ansätzen)

Neue Ansätze zur Informations- und Wissensvernetzung, sowie zur Informations- und Wissensvisualisierung in Smart Factories

Ansätze zum Einsatz von Enterprise Search in Smart Factories

Empirische Studien mit explorativem, deskriptivem oder erklärendem Charakter

\section{Akzeptierte Beiträge}

Es wurden die folgenden Beiträge zur Veröffentlichung und zur Präsentation im Workshop angenommen. Alle Beiträge wurden durch jeweils drei Gutachter begutachtet, denen wir an dieser Stelle herzlich für ihren Einsatz danken.

Gestaltung gebrauchstauglicher Assistenzsysteme für Industrie 4.0

Michael Wächter, Angelika C. Bullinger

Die Entwicklung mobiler Assistenzsysteme für die Instandhaltung stellt hinsichtlich der späteren Ak-zeptanz durch den Anwender eine große Herausforderung dar. Dieser Artikel stellt ein Konzept zur kollaborativen Entwicklung eines mobilen Assistenzsystems für Instandhalter vor. Die Anwender erhalten dabei durch die Verwendung von HardwarePrototyping schon in frühen Phasen der Produkt-gestaltung die Möglichkeit, Kriterien der Gebrauchstauglichkeit zu bewerten und mit zu gestalten. Unter Verwendung verschiedener Methoden der Produktergonomie und Designtechnik werden die einzelnen Phasen der Produktentwicklung von der Anforderungsanalyse bis zum Funktionsprototyp konzeptionell aufgezeigt.

Kollaborative Systemkonzipierung im interaktiven Entwicklungslabor

Roman Dumitrescu, Christian Tschirner, Alexander A. Albers, Lukas Bretz

In diesem Beitrag wird das Systems Engineering LIVE LAB zur Unterstützung einer erfolgreichen interdisziplinären Entwicklung mechatronischer Systeme vorgestellt. Der Bedarf für das SE LIVE LAB wurde in der Studie „Systems Engineering in der industriellen Praxis" hergeleitet (Gausemeier et al. 2013) und wird nun von der Fraunhofer-Projektgruppe Entwurfstechnik Mechatronik realisiert. Zwar liegt für Unternehmen der Nutzen von SE auf der Hand. Dennoch stellt sich häufig die Frage, wie Systems Engineering wirksam und ohne zu viel Mehrarbeit in die eigenen Prozesse integriert werden kann. Genau hier setzt das Konzept des SE LIVE LAB an. Im Beitrag werden das Konzept, die Infrastruktur sowie einige beispielhafte Nutzungsmöglichkeiten des SE LIVE LAB beschrieben. Das SE LIVE LAB liefert einen wesentlichen Beitrag zur intelligenten Fabrik, insbesondere bei der integrativen Produkt- und Produktionssystementwicklung. 
Job-Based Usability Testing to Enhance Tool-Prototyping

Stefan Rössler, Manfred Rosenberger, Markus Pirker, Daniela Gadanji, Andrea Denger, Alexander Stocker

In software development, it is long been understood that usability testing is a prerequisite to intuitive and usable user interfaces. But there is still no known method to integrate usability tests early into the development process of software, especially if it is meant to be used by specific users. The literature describes several specialist techniques to measure the usability and to set up usability experiments, but all of these involve recruiting specific users for testing, and thus risking a shortcoming of usability tests throughout the development process. This work introduce a new usability testing technique, that allows early and continuous usability testing, without the need to recruit expert users. The approach of job-based usability testing is to iteratively test and improve prototypes for software that is meant to be used by specific users to perform specific tasks and achieve specific goals, and still can be tested with average users. This new approach is expected to dramatically reduce the cost of recruiting participants for testing throughout software development projects, and hence make continuous usability testing viable.

A System Architecture for Knowledge Exchange in the Industrial Domain

Fabian Quint, Jörn Kreutel, Frieder Loch, Magnus Volkmer, Peter Pollmanns

Exchange and documentation of knowledge is vital in the industrial environment. The access to knowledge of colleagues can be essential for fulfilling several tasks. Just as well, workers can make experiences that are valuable for others. Within the project AmbiWise a collaboration system including adaptive and multimodal user interfaces for mobile interaction is developed to make knowledge easier accessible in companies. This paper presents the conception and implementation of the developed system architecture.

Multimodale Interaktion in der Produktionsstätte der Zukunft

Hermann Fürntratt, Ferdinand Fuhrmann

In diesem Beitrag stellen wir ein neuartiges multimodales Interaktionskonzept für die Produktionsstätte der Zukunft vor. Ziel ist es den Beschäftigten in seiner Interaktion mit Menschen und Geräten sowohl physisch als auch kognitiv bestmöglich zu unterstützen. Ausgehend von Kontrollräumen, mit ihren besonderen Anforderungen an die Operatoren, erweitern wir unser Interaktionskonzept auf die gesamte Produktionshalle und zeigen anhand eines umgesetzten Prototyps die technische Machbarkeit. Probleme und Herausforderungen bei der Umsetzung, sowie Verbesserungsmöglichkeiten werden im Anschluss diskutiert.

\section{Using Smart Glasses to Document Maintenance Processes}

Fabian Quint, Frieder Loch

Videos are an intuitive and maintainable way to document and transfer knowledge. Smart glasses allow to record videos hands-free from the ego-perspective with little effort. This makes them suitable devices for documenting maintenance procedures in industrial 
environments. Within the project AmbiWise mobile collaboration systems are developed to make knowledge easier accessible in companies. This paper presents an application that documents knowledge about maintenance processes using videos. A promising proof-ofconcept was implemented on Google Glass. It showed the feasibility and the use of the concept and will be evaluated under real conditions in the field within the AmbiWise project.

Visual PLM - Integrating 3D data in PLM

Reiner Schlenker, Patrick Müller, Giacomo d'Antonio

Factory floor employees need various kinds of PLM data like CAD drawings, status information, BOMs. If they have direct and easy access to the PDM/PLM software the production process can be improved in terms of efficiency and quality while the support effort for other departments decreases. To navigate and access the desired information can become a hard task for inexperienced users because the software is often quite complex to handle and the relevant information objects reside in different parts of the system. These user groups ask for an easier and visual access to the product information. The visual artifacts are created in the CAD departments and visualizing the products in the past has mainly been realized by a loose integration of 3rd party viewers or basic previews of the documents. The viewers can interpret native CAD formats and are capable of many specialized CAD features. While this improved the user experience in some scenarios there is still a gap of a complete visual access to product information. Our paper shows a different and new approach with a tighter and userfriendly integration of the 3D Viewer where the 3D model is displayed in a CAD neutral format. This allows the support of new ways of interaction and navigation within the PLM system adding value to PLM users without CAD know-how and installed CAD software.

\section{Sichere Vernetzung von Geräten in Smart Factories mit MQTT}

Martin Maritsch, Christian Kittl, Thomas Ebner

Smart Factories sind Produktionsstandorte, welche in der Lage sind, sich weitestgehend ohne menschliches Zutun zu organisieren. Dies soll durch verstärkte Kommunikation der Maschinen untereinander ermöglicht werden. Dabei spielt das Internet of Things (IoT), also die Vernetzung von Geräten, eine große Rolle um eine zentrale Datenauswertung durchzuführen. Da mitunter sensible Daten übertragen werden, ist es wichtig, auf eine geeignete Sicherung der Übertragung zu achten. Wir präsentieren das MQTT (Message Queue Telemetry Transport) -Protokoll, welches sich hierfür sehr gut eignet. Neben einigen Features, die für IoT-Anwendungen von Relevanz sind, ist es auch mit vergleichsweise geringem Aufwand möglich, die Datenübertragung zu sichern.

Mobiles Wissensmanagement in der Industrie 4.0

Peter Brandl, Helmut Aschbacher, Sabine Hösch

Wissensmanagement gewinnt in der Industrie zunehmend an Bedeutung. Informationen sollen schichtübergreifend verfügbar sein, Mitarbeiter effizient für neue Tätigkeiten qualifiziert und Wissen über Generationen hinweg vermittelt werden. Der Beitrag zeigt hierzu Konzepte und konkrete Umsetzungen basierend auf mobilen Technologien auf, die im Rahmen des Förderprojekts Assist 4.0 entwickelt und evaluiert werden. 
Kompetenzvernetzung für Wertschöpfungschampions

Steffen Kinkel, Ralph Lichtner, Brita Schemmann, Andreas P. Schmidt, Sebastian Behrendt, Michael Koch, Christine Kunzmann, Alexander Richter

Unternehmen, die über eine hohe Wertschöpfungstiefe im Wettbewerb erfolgreich sind (im Folgenden als Wertschöpfungschampions bezeichnet), müssen ein breiteres Set von Kompetenzen beherrschen als weniger integrierte Betriebe. Ein zentraler Erfolgsfaktor hierfür ist das Überblicks- und Integrationswissen erfahrener Beschäftigter, das aber im Zuge des demographischen Wandels zusehends zu erodieren beginnt. Im Projekt ChampNet soll daher ein spezifisches Konzept für die Kompetenzvernetzung und Personalentwicklung und ein dazu geeignetes System einer sozialen Medienumgebung entwickelt werden. Es soll Wertschöpfungschampions ermöglichen, die für sie zentralen Integrations- und Netzwerkkompetenzen zu identifizieren und bei einer breiten Gruppe von Beschäftigen zu verankern. Dieses soll durch attraktive Inhalte und einfache Zugänge hohe Anwendungsanreize zur Bereitstellung und Teilung individueller Kernkompetenzen gewährleisten und so Nutzungsbarrieren bei den Beschäftigten minimieren. Die Lösungen werden iterativ erprobt und umfassend evaluiert.

\section{Worker-Driven Improvement of Processes in Smart Factories}

Udo Kannengiesser, Matthias Neubauer, Chiara Di Francescomarino, Mauro Dragoni, Chiara Ghidini, Richard Heininger

This paper describes an approach to collaboratively improving processes in smart factories. It is based on the idea of a meta-process for continuous improvement that involves all stakeholders. The participation of human workers is seen as vital and is fostered using a set of technologies including wiki-based social software and the S-BPM approach to process management. The paper shows how these technologies have been incorporated in a tool developed in the ongoing Factories of the Future project SO-PC-Pro.

\section{Zehn Jahre Wissensaustausch und Communities in References+}

Johannes Müller, Jaren Krchnavi, Christina Moser, Anita Weihermann-Kollar, Heiko Jahr, Nils Hennig, Morten Torchalla, Martin Amacher, Rub n Andr Lorenzo

References+ ist eine Web-2.0-Anwendung und Community-Plattform zum unternehmensweiten Austausch von Wissen, Erfahrungen und Best Practices innerhalb des Siemens-Intranets. Ganz im Sinne von Social Networking möchte References+ alle SiemensMitarbeitende über organisatorische, hierarchische und geographische Grenzen hinweg miteinander vernetzen und diese zur direkten Kommunikation untereinander animieren. Die Plattform ist seit 2005 im Einsatz. Inzwischen sind etwa 13.000 Mitarbeitende aus über 80 Ländern und von allen Siemens-Divisionen in References+ registriert. References+ beinhaltet mehrere, für alle Teilnehmer offene Communities, welche in diesem Beitrag detailliert beschrieben werden. Der zugrunde liegende Web-2.0-Ansatz ist nicht auf bestimmte Domänen oder Berufsgruppen beschränkt und kann daher ebenso im Kontext von Smart Manufacturing, Smart Factories und Industrie 4.0 zum Einsatz kommen. 
Unified Information Access for Knowledge Workers via a Federated Recommender System

Heimo Gursch, Hermann Ziak, Roman Kern

The objective of the EEXCESS (Enhancing Europe's eXchange in Cultural Educational and Scientific reSources) project is to develop a system that can automatically recommend helpful and novel content to knowledge workers. The EEXCESS system can be integrated into existing software user interfaces as plugins which will extract topics and suggest the relevant material automatically. This recommendation process simplifies the information gathering of knowledge workers. Recommendations can also be triggered manually via web frontends. EEXCESS hides the potentially large number of knowledge sources by semi or fully automatically providing content suggestions. Hence, users only have to be able to in use the EEXCESS system and not all sources individually. For each user, relevant sources can be set or auto-selected individually. EEXCESS offers open interfaces, making it easy to connect additional sources and user program plugins.

Infor mationsvernetzungstechnologien im Bereich Automotive Engineering

Michael Spitzer, Markus Zoier, Bernd Fachbach

In der Fahrzeugentwicklung werden diverse Tools, Daten und Informationen verwendet und generiert. Auch in der Produktion (Smart Factory) werden immer größere Datenmengen verarbeitet. Um die anfallenden Daten und Informationen effizient zur Verfügung zu stellen, hat sich das Forschungsprojekt FIND zum Ziel gesetzt, einen flexiblen und effizienten Zugriff auf diese heterogenen Daten und Informationen $\mathrm{zu}$ ermöglichen. Es zeigte sich, dass im Automotive-Umfeld bereits verschiedene Suchtechnologien eingesetzt werden, die Qualität und Zufriedenheit mit diesen Technologien jedoch begrenzt ist. Nach intensiver Vorbereitung und Erfassung der Use Cases wurden unter Berücksichtigung zur Verfügung gestellter Beispieldaten der Projektpartner verschiedene Architekturen und Technologien evaluiert. Vielversprechende Technologien wurden in Folge in einem Prototyp implementiert. Hierbei wurde großen Wert auf Flexibilität und Austauschbarkeit der ausgewählten Technologien gelegt und auf eine saubere Trennung der einzelnen Komponenten geachtet. Das Frontend wurde unter besonderer Berücksichtigung der Schnittstelle Mensch - Computer angepasst und ermöglicht eine domänenspezifische Sicht auf die verfügbaren Daten. Der Prototyp befindet sich derzeit in der Review Phase bei den jeweiligen Projektpartnern.

Smart Engineering for Smart Factories: How OSLC Could Enable Plug \& Play Tool Integration

Christian Kaiser, Beate Herbst

In this paper OSLC (Open Services for Lifecycle Collaboration) is proposed as key element in an approach for tool integration. OSLC enables data exchange and resource linking across tools within smart engineering, assisting thereby factories in behaving smart. According to OSLC's description, a core specification and several domain specifications assist software developers in implementing standardized interfaces for information exchange, which allow low-cost exchangeability of tools providing the same type of data. Due to the resource linking 
approach of OSLC (instead of data synchronization), the typical integration challenges of traceability, data consistency and data interoperability across the whole lifecycle process are appropriately managed and therefore assist collaboration, reuse and integration. Traceability across engineering tools can be a key enabler for smart factories. However, applied to the whole engineering process of a smart production lifecycle, which is in this approach based on the V-model, advantages and challenges yet to be solved of this approach arise, which is why this paper focuses engineering to be able to assist smart factories in future.

\section{Liter atur ver zeichnis}

Denger, A., Stocker, A., Schmeja, M. (2012): Future Workplace - Eine Untersuchung sozio-technischer Einflüsse auf den Arbeitsplatz der Zukunft. Shaker Verlag, Aachen.

Denger, A., Fritz, J.; Denger, D.; Priller, P.; Kaiser, C.; Stocker, A. (2014): Organisationaler Wandel durch die Emergenz Cyber-Physikalischer Systeme: Die Fallstudie AVL List GmbH, HMD Praxis der Wirtschaftsinformatik, Heft 300.

Hansen, H.R., Neumann, G. (2009): Wirtschaftsinformatik 1. Grundlagen und Anwendungen, Lucius und Lucius Verlagsgesellschaft.

Porter, M.; Heppelmann, J.E. (2014): How Smart, Connected Products are Transforming Competition, Harvard Business Review.

Richter, A. (2014): Vernetzte Organisation. Oldenbourg Wissenschaftsverlag.

Richter, A., Bullinger, A. (2010): Enterprise 2.0 - Gegenwart und Zukunft, Vorschlag einer Forschungsagenda, Multikonferenz Wirtschaftsinformatik (MKWI).

Spath, D., Ganschar, O., Gerlach, S., Hämmerle, M., Krause, T., Schlund, S. (2014). Produktionsarbeit der Zukunft - Industrie 4.0, Studie von Fraunhofer IAO.

Stocker, A.; Brandl, P.; Michalczuk, R.; Rosenberger, M. (2014): Mensch-zentrierte IKT-Lösungen in einer Smart Factory, e \& i Elektrotechnik und Informationstechnik, Volume 131, Issue 7.

Stocker, A., Tochtermann, K. (2012): Wissenstransfer mit Wikis und Weblogs. Fallstudien für den erfolgreichen Einsatz von Web 2.0 in Unternehmen, Gabler Research, 2. Auflage.

Teufel, S., u .a.: Computerunterstützung für die Gruppenarbeit. Bonn 1995.

\section{Kontaktinformationen}

Dr. Alexander Stocker, Information \& Process Management, Virtual Vehicle Research Center, Graz

DI (FH) Andrea Denger, Information \& Process Management, Virtual Vehicle Research Center, Graz

Martin Wifling, Projektleitung FACTS4WORKERS, Virtual Vehicle Research Center, Graz DI Johannes Fritz, BSc, Information \& Process Management, Virtual Vehicle Research Center, Graz

DI Christian Kaiser, Information \& Process Management, Virtual Vehicle Research Center, Graz

Dr. Christian Kittl, Geschäftsführung, evolaris next level gmbh, Graz

Dr. Alexander Richter, Department of Informatics, University of Zurich, Zurich 